\section{Summer Breeze}

\section{Top 10 Advocacy Shortutus for the Time-Pressed}

JENNA NEMEC-LOISE

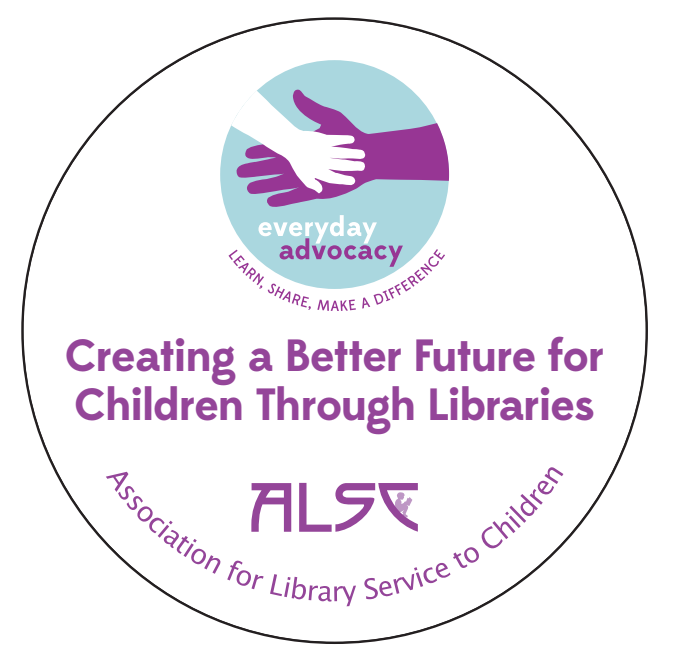

form available on the Everyday Advocacy website. (Find it on the home page under "Advocacy Button Campaign.")

2. Wear your advocacy button. If you've got it, flaunt it! Wear your button proudly and use it to spread the word about the importance of library service to children among your stakeholders.

3. Download the advocacy button tip sheet. Need a few talking points to use with your button? Download the "Creating a Better Future" tip sheet from the Everyday Advocacy website to help you get started.

4. Take action on Tuesdays. For worry-free advocacy scheduling, be a part of our weekly Take Action Tuesday challenges. Why go out looking for an idea when we'll bring one right to you?

5. Tweet. Twitter is an Everyday Advocate's best friend. You've only got 140 characters, so make 'em count! Don't have an account? It just takes a few minutes to sign up. (You know you want to.)

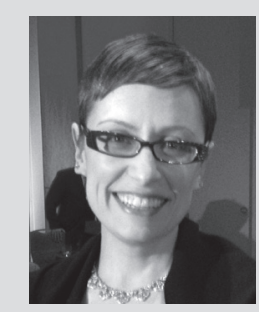

Jenna Nemec-Loise is Member Content Editor, ALSC Everyday Advocacy website and electronic newsletter. Everyday Advocacy empowers ALSC members to embrace their roles as library advocates by focusing on their daily efforts to serve youth and families. Each lighthearted column features easy-to-implement strategies and techniques for asserting the transformative power of libraries both within communities and beyond them. Please contact Jenna Nemec-Loise at everyday-advocacy@hotmail.com with comments and ideas for future topics. 
6. Scan the July issue of Everyday Advocacy Matters. You'll find lots of quick ways to get your advocacy on in this quarterly newsletter filled with ready-to-go tips, tools, and techniques.

7. Subscribe to District Dispatch. Get the latest action alerts from the ALA Washington Office as well as the 4-1-1 on contacting your US legislators.

8. Jot down stories. Summer is the perfect time to start a database of impact stories that complement your elevator speeches about what you do and why it's important.
9. Tell a friend. Have a colleague who could use this list, too? Take a time-out for a quick phone call, e-mail, or conversation that encourages another Everyday Advocate.

\section{Repeat 1-9. Enough said.}

Have other great ideas for making advocacy a breeze this summer? Let us know so we can share them with other ALSC members! ¿

RESULIS FROM THE YOUNG CHILDREN, continued from page 32

Childhood Programs Serving Children from Birth through Age 8," 2012, www.naeyc.org/files/naeyc/PS_technology_ WEB.pdf (accessed October 21, 2014).

19. Reed Stevens and William R. Penuel, Studying and Fostering Learning through Joint Media Engagement, Paper Presented at the Principal Investigators Meeting of the National Science Foundation's Science of Learning Centers, Arlington, Va., 2010; Takeuchi and Stevens, The New Coviewing.

20. "ECRR 2.0-Using Apps and eBooks in Early Literacy Programs," Presentations at Public Library Association Conference and American Library Association Conference in 2014.

21. Fran Simon, Karen Nemeth, and Dale McManis, "Technology in ECE Classrooms," Child Care Information Exchange, September/October 2013, https:// hatchearlylearning.com/?wpfb_dl=275 (accessed October 12, 2014).
22. Lucey and Della Penna, "Once Upon an App."

23. Researcher Emily Romeijn-Stout also contributed to the data analysis.

24. The total of 415 respondents includes five duplicate submissions; that is, five libraries submitted two copies of the survey, each with different responses (presumably by two different staff members). This may contribute to an error percentage of .01 .

25. Cen Campbell and Amy Koester, "New Media in Youth Librarianship," in Young Children, New Media, and Libraries: A Guide for Incorporating New Media into Library Collections, Services, and Programs for Families and Children Ages 0-5, edited by LittleeLit and Amy Koester, published under a Creative Commons AttributionNonCommercial-NoDerivatives 4.0 International License, 2014.

26. Guernsey, Screen Time.
ALSC has released a new white paper, "Media Mentorship in Libraries Serving Youth," written for the association by Cen Campbell, Claudia Haines, Amy Koester, and Dorothy Stoltz, and adopted by the ALSC Board of Directors in March 2015. The paper explores the role of children's librarians as mentors of digital media and calls on youth service librarians to support families in their intentional, appropriate, and positive use of media.

\section{About the authors}

Cen Campbell is a children's librarian and the founder at LittleeLit. com. Claudia Haines is the Youth Services Librarian at the Homer (Alaska) Public Library. Amy Koester is Youth \& Family Program Coordinator at Skokie (III.) Public Library. Dorothy Stoltz coordinates programming and outreach services at Carroll County (Md.) Public Library.

Download your copy at www.ala.org/alsc/mediamentorship.
Media Mentorship in Libraries

Serving Youth

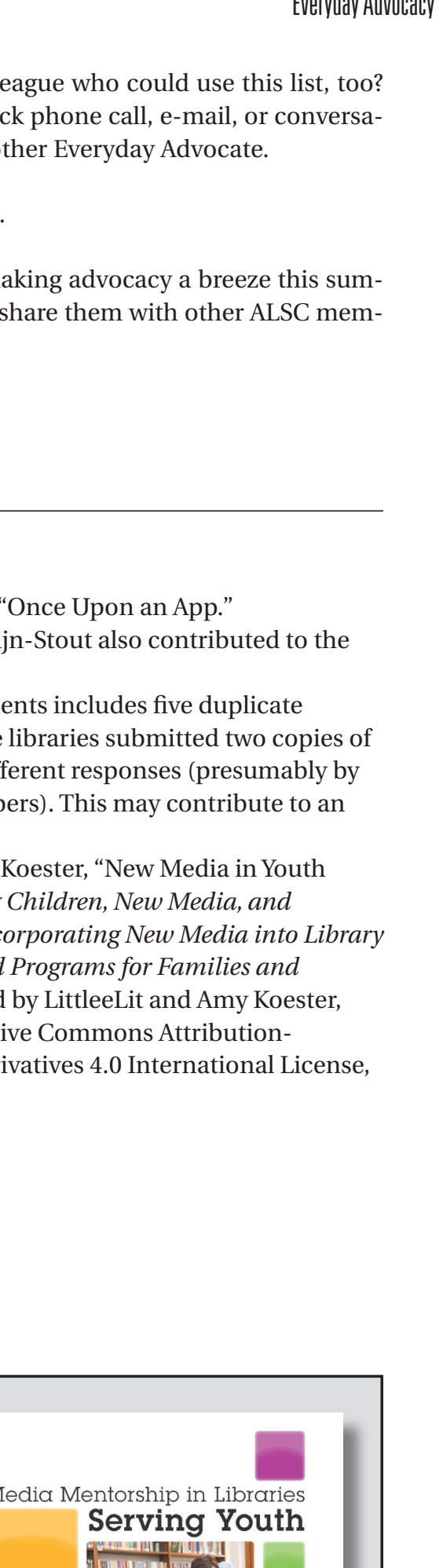

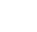

(1)

(1)

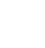

(1)

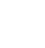

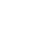

